Aranta Prista Dilasari: Analisis Komparatif Tentang Komitmen Wajib Pajak

\title{
ANALISIS KOMPARATIF TENTANG KOMITMEN WAJIB PAJAK DALAM MEL- APORKAN SURAT PEMBERITAHUAN (SPT) PAJAK PADA PERHOTELAN DAN RESTORAN DI SEMARANG
}

\author{
Aranta Prista Dilasari \\ Universitas Airlangga \\ Email:arantadila@yahoo.com
}

\begin{abstract}
The problem raised in this study is the commitment of the Tax Return Annual Report (SPT) based on the RI Taxation Law No. 36 of 2008 Article 17 of hotels and restaurants. This study uses a combined approach, which is operationally trying to qualify quantitative results and quantify qualitative results, where the results will be measured based on research indicators for each data group. Furthermore, it was measured using an analysis of the $t$ test (independent sample test) separated variance to get the results of the comparison between the tax return reporting commitment from hospitality with restaurants. The results showed that most of the hotels had high commitments, but there were still 18 companies that were in the Low and Very Low categories. Whereas in most restaurants the number of companies has a high commitment, but there are still 5 companies that have the category of Low and Very Low. The tax return reporting commitment between hospitality and restaurants has a significant difference.
\end{abstract}

Keyword: commitment, tax return reporting

\section{ABSTRAK}

Permasalahan yang dikemukakan pada penelitian ini adalah komitmen Pelaporan Surat Pemberitahuan Tahunan (SPT) Pajak berdasarkan Undang-Undang Perpajakan RI No. 36 Tahun 2008 pasal 17 pada perhotelan dan restoran.Penelitian ini menggunakan pendekatan gabungan, yaitu secara operasional mencoba mengkualitatifkan hasil kuantitatif dan mengkuantitatifkan hasil kualitatif, dimana hasilnya akan diukur berdasarkan indikator penelitian untuk masing-masing kelompok data. Selanjutnya diukur dengan menggunakan analisis uji t (independent sampel test) separated varians untuk mendapatkan hasil perbandingan antara komitmen pelaporan SPT pajak dari perhotelan dengan restoran.Hasil penelitian menunjukkan sebagian besar jumlah perhotelan memiliki komitmen tinggi, namun masih terdapat 18 perusahaan yang memiliki kategori Rendah dan Sangat Rendah. Sedangkan pada restoran sebagian besar jumlah perusahaan memiliki komitmen Tinggi, namun masih terdapat 5 perusahaan yang memiliki kategori Rendah dan Sangat Rendah. Komitmen pelaporan SPT pajak antara perhotelan dengan restoran memiliki perbedaan yang signifikan.

Kata kunci: komitmen, pelaporan SPT pajak 
Ihtiyath Vol. 2 No. 1 September 2018

\section{PENDAHULUAN}

Reformasi kebijakan perpajakan tersebut diharapkan dapat meningkatkan penerimaan pajak, daya saing dan iklim investasi melalui penyerdehanaan jenis pajak dan struktur tarif yang berlaku di negara-negara lain. Sehubungan dengan perkembangan globalisasi khususnya di bidang ekonomi maka tidak dielakkan timbulnya persaingan antar negara dalam rangka menarik investasi. Dalam hal ini perlu mendapat perhatian dengan hal-hal yang berkaitan dengan struktur tarif pajak, pemberian fasilitas perpajakan, dan penyempurnaan sistem dan prosedur restitusi pajak.

Adapun perubahan pada Undang-Undang Pajak Penghasilan antara lain adalah: adanya masalah berubahnya Penghasilan Tidak Kena Pajak (PTKP), tarif pajak yang diterapkan atas Penghasilan Kena Pajak bagi wajib pajak dalam negeri dan kewajiban untuk memiliki NPWP untuk orang pribadi yang bekerja pada satu pemberi kerja. Sejalan dengan usul perubahan Undang-undang material perpajakan dan perkembangan teknologi informasi, maka beberapa definisi dalam Undang-undang tentang Ketentuan Umum dan Tatacara Perpajakan perlu disesuaikan dan atau ditambah antara lain definisi: Badan, Surat Setoran Pajak, Surat Keputusan Pembetulan, Putusan Peninjauan Kembali, Surat Keputusan Pemberian Imbalan Bunga dan Nomor Identitas Bersama. Perlu ditegaskan bahwa Wajib Pajak yang diberikan Nomor Pokok Wajib Pajak dan atau yang dikukuhkan sebagai Pengusaha Kena Pajak, maka pemenuhan kewajiban perpajakannya dimulai sejak saat Wajib Pajak memenuhi persyaratan subjektif dan persyaratan objektif berdasarkan ketentuan perundang-undangan perpajakan.

Dampak dari perubahan Rancangan Undang-undang Pajak penghasilan pasal 21 adalah perubahan tarif pajak yang mana bagi Wajib Pajak akan ada keringanan dalam pembayaran pajak dan diharapkan akan adanya ketertiban di dalam pelaporan dan pembayaran pajak. Selain perubahan tarif pajak juga diharapkan pada Wajib Pajak yang belum memiliki NPWP untuk mendaftarkan diri untuk memiliki NPWP.

Komitmen pelaporan SPT pajak dari perhotelan maupun restoran menunjukkan masih banyak perusahaan yang belum memahami mekanisme pelaporan SPT pajak sebagaimana mestinya, sehingga dalam setiap pengisiannya masih dilakukan dengan cara yang tidak memperhatikan ketentuan-ketentuan yang berlaku. Dampak yang ditimbulkan dari komitmen pelaporan SPT yang tidak sesuai ketentuan tersebut, tidak hanya dirasakan oleh pemerintah sebagai penerima pendapatan pajak, tetapi juga wajib pajak yang ber- 
Aranta Prista Dilasari: Analisis Komparatif Tentang Komitmen Wajib Pajak

sangkutan, apabila perhitungan yang dilakukan tidak akurat sehingga akan berdampak pada penyetoran pajak yang terlalu besar.

\section{KERANGKA TEORITIS DAN HIPOTESIS Komitmen}

Komitmen adalah kemampuan dan kemauan untuk menyelaraskan perilaku pribadi dengan kebutuhan, prioritas dan tujuan organisasi. Hal ini mencakup cara-cara mengembangkan tujuan atau memenuhi kebutuhan organisasi yang intinya mendahulukan misi organisasi dari pada kepentingan pribadi (Soekidjan, 2012). Menurut Meyer dan Allen (dalam Soekidjan, 2012), komitmen dapat juga berarti penerimaan yang kuat individu terhadap tujuan dan nilai-nilai organisasi, dan individu berupaya serta berkarya dan memiliki hasrat yang kuat untuk tetap bertahan di organisasi tersebut.

Menurut Van Dyne dan Graham (2013, dalam Muchlas, 2012), faktor-faktor yang mempengaruhi komitmen organisasi adalah: personal, situasional dan posisi. Personal mempunyai ciri-ciri kepribadian tertentu yaitu teliti, ektrovert, berpandangan positif(optimis), cendrung lebih komit. Lebih lanjut Dyen dan Graham (2013, dalam Muchlas, 2012) menjelaskan karakteristik dari personal yang ada yaitu: usia, masa kerja, pendidikan, jenis kelamin, status perkawinan, dan keterlibatan kerja. Situasional yang mempunyai ciri-ciri dengan adanya: nilai (value) tempat kerja, keadilan organisasi, karakteristik pekerjaan, dan dukungan organisasi. Sedangkan posisional dipengaruhi oleh masa kerja dan tingkat pekerjaan.

Berdasarkan pengertian-pengertian tersebut, maka dapat diambil gambaran bahwa komitmen merupakan suatu nilai dari kemauan untuk menyelaraskan perilaku pribadi dengan kebutuhan, prioritas dan tujuan organisasi serta penerimaan yang kuat dari individu tersebut terhadap tujuan dan nilai-nilai organisasi.

\section{Pengertian Pajak}

Definisi pajak menurut Muqodim (2012:1) adalah suatu pengalihan sumber-sumber yang wajib dilakukan dari sektor swasta (dalam pengertian luas) kepada sektor pemerintah (kas negara) berdasarkan Undang-undang atau peraturan, sehingga dapat dipaksakan, tanpa ada kontraprestasi yang langsung dan seimbang yang dapat ditunjukkan secara individual dan hasil penerimaan pajak tersebut merupakan sumber penerimaan negara yang akan digunakan untuk pengeluaran pemerintah baik pengeluaran rutin maupun pengeluaran pembangunan. Swasta dalam pengertian luas termasuk perusahaan negara 
dan daerah.

Pajak diperuntukkan bagi pengeluaran-pengeluaran pemerintah, yakni pengeluaran-pengeluaran yang bermanfaat bagi masyarakat luas, yang bila dari pemasukannya masih terdapat surplus, dipergunakan untuk membiayai public investment.

Menurut Mardiasmo (2012:1) pajak adalah iuran rakyat kepada kas negara berdasarkan undang-undang (yang dipaksakan) dengan tiada mendapat jasa timbal (kontraprestasi) yang langsung dapat ditujukan dan digunakan untuk membayar pengeluaran umum. Berdasarkan definisi tersebut, pajak memiliki unsur yang berhak memungut pajak hanyalah Negara, dipungut berdasarkan atau dengan kekuatan undang-undang serta aturan pelaksanaannya, tanpa jasa timbal balik atau kontraprestasi dari negara yang secara langsung dapat dirasakan, dan digunakan untuk membiayai rumah tangga negara.

Menurut Sumitro (2010:79), Pajak adalah iuran rakyat kepada kas negara berdasarkan Undang-undang (yang di paksakan) dengan tidak mendapat jasa timbal balik (Kontraprestasi) yang langsung dapat ditunjukkan dan yang digunakan untuk membayar pengeluaran umum.

Suandy (2012:75) menyatakan bahwa Pajak penghasilan adalah pajak yang di kenakan terhadap subjek pajak atas penghasilan yang di terima atau di perolehnya dalam tahun pajak atau dapat pula di kenakan pajak untuk penghasilan dalam bagian tahun pajak, apabila kewajiban pajak subjektifnya di mulai atau berakhir dalam tahun pajak.

\section{Jenis-jenis Pajak}

Terdapat berbagai macam jenis pajak yang dapat dikelompokkan menjadi tiga, yaitu pengelompokan menurut golongannya, menurut sifatnya, dan menurut lembaga pemungutnya (Resmi, 2003:6).

Menurut golongannya, pajak dikelompokkan menjadi dua, yaitu:

Pajak Langsung adalah pajak yang harus dipikul atau ditanggung sendiri oleh Wajib Pajak dan tidak dapat dilimpahkan atau dibebankan kepada orang lain atau pihak lain. Pajak harus menjadi beban sendiri oleh Wajib Pajak yang bersangkutan. Sebagai contoh adalah Pajak Penghasilan. Pajak Penghasilan dibayar atau ditanggung oleh pihak-pihak tertentu yang memperoleh penghasilan tersebut. 
Aranta Prista Dilasari: Analisis Komparatif Tentang Komitmen Wajib Pajak

Pajak Tidak Langsung adalah pajak yang pada akhirnya dapat dibebankan atau dilimpahkan kepada orang lain atau pihak ketiga. Pajak tidak langsung terjadi jika terdapat suatu kegiatan, peristiwa, perbuatan yang menyebabkan terutangnya pajak. Pajak Pertambahan Nilai merupakan salah satu dari kategori ini.

Menurut sifatnya pajak terdiri dari pajak subjektif yaitu pajak yang berpangkal atau berdasarkan pada subjeknya, dalam arti memperhatikan keadaan diri Wajib Pajak, dan pajak objektif, yaitu pajak yang berpangkal pada objeknya tanpa memperhatikan keadaan diri Wajib Pajak.

Menurut lembaga pemungutnya, pajak terdiri dari pajak pusat, yaitu pajak yang dipungut oleh pemerintah pusar dan digunakan untuk membiayai rumah tangga Negara dan pajak daerah, yaitu pajak yang dipungut oleh Pemerintah Daerah dan digunakan untuk membiayai rumah tangga daerah

\section{Fungsi dan Tata Cara Pemungutan Pajak}

Menurut Ilyas dan Waluyo (2012:8) menyatakan ada dua fungsi pajak, yaitu Fungsi Penerimaan (Budgeter), yaitu pajak yang berfungsi sebagai sumber dana yang diperuntukkan bagi pembiayaan pengeluaran pemerintah, dan fungsi mengatur (Regular) yaitu pajak yang berfungsi sebagai alat untuk mengatur atau melaksanakan kebijakan di bidang sosial ekonomi.

Ilyas dan Waluyo (2012:15) juga menyatakan bahwa pemungutan pajak dapat di lakukan berdasarkan tiga stelsel pajak, yaitu:

\section{Stelsel Nyata (Riel Stelsel)}

Pengenaan pajak didasarkan pada obyek pajak (penghasilan nyata), sehingga pemungutannya baru dapat di lakukan pada akhir tahun pajak, yakni setelah penghasilan yang sesungguhnya diketahui.

2. Stelsel Anggapan (Fictive Stelsel)

Pengenaan pajak di dasarkan pada suatu anggapan yang diatur oleh Undang-undang.

3. Stelsel Campuran

Stelsel ini merupakan kombinasi antara stelsel nyata dan stelsel anggapan. Pada 
Ihtiyath Vol. 2 No. 1 September 2018

awal tahun besarnya pajak dihitung berdasarkan suatu anggapan, kemudian pada akhir tahun besarnya pajak di sesuaikan dengan keadaan yang sebenarnya.

Menurut ketentuan dalam surat keputusan Menteri Keuangan nomor 541/KMK.04 /2000 diatur mengenai penyetoran pajak diatur sebagai berikut:

- $\quad$ Ketentuan pasal 1 ayat (2) adalah pajak penghasilan (PPh) sebagaimana dimaksud dalam pasal 23 dan pasal 26 undang-undang nomor 7 tahun 1983 tentang pajak penghasilan (PPh) sebagaimana telah diubah terakhir dengan undang-undang nomor 17 tahun 2000, harus disetor paling lambat tanggal 10 (sepuluh) bulan takwim berikutnya setelah bulan saat terutangnya pajak.

- $\quad$ Ketentuan pasal 2 adalah dalam hal jatuh tempo pembayaran atau penyetoran bertepatan dengan hari libur, maka pembayaran atau penyetoran dapat dilakukan pada hari kerja berikutnya.

- $\quad$ Pasal 3 adalah pembayaran dan penyetoran pajak dilakukan di kantor pos atau bank badan usaha milik Negara atau bank badan milik daerah, atau bank-bank lain yang ditunjuk oleh Direktur Jenderal Anggaran.

- $\quad$ Pasal 4 adalah pembayaran dan penyetoran pajak harus dilakukan dengan menggunakan surat setor pajak (SSP) atau sarana administrasi lain yang ditetapkan oleh Direktur Jenderal Pajak. Menurut ketentuan undang-undang nomor 16 tahun 2000 KUP diatur mengenai pelaporan pajak sebagai berikut:

Ketentuan pasal 3 ayat (3) adalah batas waktu penyampaian surat pemberitahuan adalah:

a. Untuk surat pemberitahuan masa, paling lambat 20 (dua puluh) hari setelah masa pajak.

b. Untuk surat pemberitahuan tahunan, paling lambat 3 (tiga) bulan setelah akhir tahun pajak.

Ketentuan pasal 3 ayat (4) adalah Direktur Jenderal Pajak atas permohonan Wajib Pajak dapat memperpanjang jangka waktu penyampaian surat pemberitahuan sebagaimana dimaksud dalam ayat (3) huruf b paling lama 6 (enam) bulan.

Ketentuan pasal 4 ayat (1) adalah Wajib Pajak wajib mengisi dan menyampaikan surat pemberitahuan dengan benar, lengkap, jelas dan menandatanganinya. 
Aranta Prista Dilasari: Analisis Komparatif Tentang Komitmen Wajib Pajak

Ketentuan pasal 6 ayat (1) adalah surat pemberitahuan yang disampaikan langsung oleh Wajib Pajak ke kantor Direktorat Jenderal Pajak harus diberi tanggal penerimaan oleh pejabat yang ditunjuk untuk itu, sedangkan untuk syarat pemberitahuan tahunan harus diberikan juga bukti penerimaan.

Ketentuan pasal 6 ayat (2) adalah penyampaian surat pemberitahuan dapat dikirimkan melalui kantor pos secara tercatat atau dengan cara lain yang diatur dengan keputusan Direktorat Jenderal Pajak.

Ketentuan pasal 9 ayat (2) adalah kekurangan pembayaran pajak yang terutang berdasarkan surat pemberitahuan tahunan harus dibayar lunas paling lambat tanggal 20 bulan ke-3 setelah tahun pajak atau bagian tahun pajak berakhir, sebelum surat pemberitahuan itu disampaikan.

Ketentuan pasal 10 ayat (1) adalah Wajib Pajak membayar atau menyetor pajak yang terutang di kas Negara melalui Kantor Pos dan atau Bank Usaha Milik Negara atau Bank Badan Usaha Milik Daerah atau tempat pembayaran lain yang ditetapkan oleh Menteri Keuangan.

Adapun batas waktu penyampaian atau Pelaporan SPT Masa pajak penghasilan (PPh) yaitu tanggal 20 bulan takwim berikutnya setelah masa pajak berakhir. Jika tanggal 20 jatuh pada hari libur maka SPT Masa disampaikan pada hari kerja sebelumnya. SPT Masa pajak penghasilan (PPh) terdiri dari:

- $\quad$ Lembar ke-1 untuk Kantor Pelayanan Pajak (KPP).

- $\quad$ Lembar ke-2 untuk Pemotong Pajak.

Untuk mengatasi masalah-masalah tersebut perlu melakukan upaya:

1. Berusaha mencatat besarnya pungutan dari rekanan dari setiap perubahan yang ada langsung dikoreksi.

Apabila terjadi kesalahan dalam pencatatan dan penghitungan, maka melakukan pembetulan pada Surat Pemberitahuan (SPT) pajak penghasilan (PPh) sebelum dilakukan penyetoran. 
Ihtiyath Vol. 2 No. 1 September 2018

Agar memudahkan proses pencatatan dan penghitungan, maka semua kegiatan ini dilakukan dengan menggunakan teknologi komputer guna mencapai hasil yang lebih efisien dan efektif.

\section{Surat Pemberitahuan (SPT)}

Surat Pemberitahuan (SPT) menurut Pasal 1 angka 10 UU RI No. 6 tahun 1983 sebagaimana telah beberapa kali diubah dengan UU RI No. 16 tahun 2000 tentang KUP, menyebutkan yang dimaksud dengan SPT adalah surat yang oleh wajib pajak digunakan untuk melaporkan perhitungan dan atau pembayaran pajak, objek pajak/bukan objek pajak dan atau harta dan kewajiban menurut ketentuan peraturan perundang-undangan perpajakan.

Adapun fungsi SPT berdasarkan penjelasan pasal 3 ayat 1 UU RI No. 6 ahun 1983 sebagaimana telah beberapa kali diubah dengan UU Ri No. 16 tahun 2000 tentang KUP adalah:

Fungsi SPT bagi wajib pajak penghasilan sebagai sarana untuk melaporkan dan mempertanggungjawabkan perhitungan jumlah pajak yang sebenarnya terutang dan untuk melaporkan tentang:

1. Pembayaran/pelunasan pajak yang telah dilaksanakan sendiri dan tahun pajak/bagian tahun pajak.

2. Penghasilan yang merupakan orang pribadi dan atau badan objek pajak.

\section{Harta dan Kewajiban}

Pembayaran dari pemotong/pemungut tentang pembatalan orang pribadi/badan lain dalam 1 masa pajak yang dilakukan perundang-undangan perpajakan yang berlaku.

Bagi pengusaha kena pajak fungsi SPT adalah sebagai sarana untuk melaporkan dan mempertanggungjawabkan penghitungan jumlah pajak pertambahan nilai dan pajak penjualan atas barang mewah yang sebenarnya terutang dan untuk melaporkan tentang:

\section{Pengkreditan pajak masukan terhadap pajak keluaran.}

Pembayaran/pelunasan pajak yang telah dilaksanakan sendiri oleh pengusaha kena pajak melalui pihak lain dalam suatu masa pajak yang ditentukan oleh ketentuan umum perpajakan perundang-undangan. 
Aranta Prista Dilasari: Analisis Komparatif Tentang Komitmen Wajib Pajak

Bagi pemotong/pemungut pajak fungsi SPT adalah sabagai sarana untuk melaporkan dan mempertanggung jawabkan pajak yang dipotong/ dipungut dan disetorkannya.

Jenis-Jenis SPT Bila diperhatikan saat pelaporannya SPT dibedakan menjadi 2 bagian, yaitu:

1. SPT Masa adalah surat yang oleh wajib pajak digunakan untuk melaporkan penghitungan dan/pembayaran pajak yang terutang dalam suatu masa pajak/pada suatu saat. 2. SPT Tahunan adalah surat yang oleh wajib pajak digunakan untuk melaporkan perhitungan dan pembayaran pajak yang terutang dalam satu tahun pajak.

Sesuai dengan pasal 2 ayat 3 UU RI No. 6 tahun 1983 sebagimana beberapa kali diubah dengan UU RI No. 16 tahun 2000 tentang KUP, batas penyampaian SPT adalah:

Untuk SPT Masa paling lambat 20 hari setelah akhir masa pajak Untuk SPT Tahunan paling lambat 3 bulan setelah akhir tahun pajak.

\section{Hipotesis Penelitian}

$\mathrm{H}_{\mathrm{o}}$ : Tidak terdapat perbedaan yang signifikan mengenai komitmen wajib pajak dalam melaporkan SPT pajak antara perhotelan dan restoran.

$\mathrm{H}_{\mathrm{a}}$ : Terdapat perbedaan yang signifikan mengenai komitmen wajib pajak dalam melaporkan SPT pajak antara perhotelan dan restoran.

\section{METODE PENELITIAN}

\section{Pendekatan Penelitian}

Pendekatan yang digunakan dalam penelitian adalah pengukuran terhadap komitmen dari wajib pajak dalam melaporkan SPT antara perhotelan dan restoran di Kota Semarang. Analisis hasil penelitian lebih dominan dengan menggunakan metode kuantitatif, sedangkan analisis secara kualitatif digunakan sebagai penalaran terhadap pembahasan. Penelitian ini menggunakan tipe penelitian yang bersifat komparatif yaitu penelitian yang bertujuan memberikan gambaran membandingkan perhotelan dan restoran mengenai komitmen wajib pajak dalam pelaporan SPT pajak berdasarkan Undang-Undang Perpajakan RI No. 36 Tahun 2008 pasal 17 untuk wajib pajak badan.

\section{Definisi Operasional Variabel}

Pembahasan dalam penelitian ini adalah komitmen wajib pajak dalam melaporkan SPT pajak oleh perhotelan dan restoran di Kota Semarang yang mengacu pada Undang-Un- 
Ihtiyath Vol. 2 No. 1 September 2018

dang Perpajakan Nomor 30 Tahun 2008 pasal 17. Adapun indikator-indikator pelaporan SPT pajak berdasarkan peraturan tersebut secara lebih jelasnya adalah sebagai berikut: Penghitungan penghasilan bersih, yaitu penerapan norma perhitungan atas penghasilan bersih yang didapat perusahaan setelah dikurangi biaya-biaya yang berkaitan dengan pengenaan pajak. Isian perhitungan penghasilan bersih ini dicantumkan dalam kolom isian di SPT pajak.

Pengisian Penghasilan Tidak Kena Pajak (PTKP), yaitu tata cara pengisian yang dilakukan oleh perusahaan terhadap pendapatan-pendapatan yang tidak terkena tarif pajak, seperti pendapatan lain-lain, pendapatan bunga dan pendapatan non operasional lainnya. Pendapatan tidak kena pajak ini berfungsi untuk mengurangi jumlah pajak yang disetorkan yang dihitung berdasarkan pendapatan perusahaan.

Pengenaan tarif PPh Obyek Pajak, yaitu keakuratan perhitungan dasar pengenaan tarif Pajak Penghasilan (PPh) atas obyek pajak. Tarif yang berlaku atau perhitungan jumlah setoran pajak akan disesuaikan berdasarkan nilai persentase dari tarif pajak yang telah ditetapkan.

Kelengkapan Data Pengisian SPT Pajak, yaitu kebenaran atas kelengkapan data-data mengenai informasi obyek pajak serta komponen-komponen yang berkenaan dengan karakteristik obyek pajak.

\section{Teknik Pengumpulan Data}

Data yang diambil dari penelitian ini menggunakan data Primer yang diperoleh langsung dari Kantor Pelayanan Pajak Pratama Semarang terhadap objek wajib pajak yang diteliti. Sedangkan data sekunder adalah data yang didapat dari obyek penelitian yaitu perhotelan dan restoran di Kota Semarang untuk mendapatkan informasi mengenai gambaran umum perusahaan, perkembangan usaha, dan pengelolaan pajak di perusahaan.

Berdasarkan jenis dan sumber data di atas, maka teknik yang digunakan untuk pengumpulannya adalah dengan teknik observasi, dengan mengumpulkan data-data pelaporan SPT yang dilakukan oleh wajib pajak berdasarkan instrumen penelitian pada Kantor Pelayanan Pajak Pratama Semarang pada perhotelan dan restoran. 


\section{Analisis}

Hasil pengujian dengan menggunakan analisis uji $t$ (independent sampel test) separated varians dengan $n_{1}=n_{2}$ dengan menggunakan rumus sebagai berikut:

Rumus:

$\mathrm{t}=$

Keterangan:

$\mathrm{X}_{1}=\quad$ Komitmen Wajib Pajak Perhotelan

$\mathrm{X}_{2}=\quad$ Komitmen Wajib Pajak Restoran

$\mathrm{S}_{1}=$ Standar Deviasi rata-rata Komitmen Wajib Pajak Perhotelan

$\mathrm{S}_{2}=\quad$ Standar Deviasi rata-rata Komitmen Wajib Pajak Restoran

$\mathrm{N}_{1}=$ Jumlah Sampel Perhotelan

$\mathrm{N}_{2}=$ Jumlah Sampel Restoran

Untuk pengujian hipotesis, maka t-hitung akan diakumulasikan dengan nilai t-tabel dengan taraf kepercayaan 95\% (x 0,05) dengan derajat kebebasan ( $d k$ ) $\mathrm{N}_{1}+\mathrm{N}_{2}-2$. Bila t-tabel lebih besar dari t-hitung $\left(t_{H}<t_{t}\right)$ maka hipotesis nol diterima dan bila nilai t-tabel lebih kecil dari t-hitung $\left(t_{H}>t_{t}\right)$ maka hipotesis alternatif diterima. Apabila pengambilan keputusan didasarkan pada hasil output SPSS, maka pengambilan keputusannya dilakukan dengan membandingkan nilai signifikan pada kolom sig. Dengan taraf signifikan yang digunakan (0,05).

\section{HASIL DAN PEMBAHASAN}

Kategori komitmen wajib pajak dalam melaporkan SPT Pajak, dapat dilihat pada hasil analisis perhitungan sebagai berikut:

\section{Perhotelan}

Penghitungan Penghasilan Bersih

Penilaian komitmen dalam perhitungan penghasilan bersih dari perhotelan adalah sebesar 106 poin, dimana berdasarkan persentase poin tersebut didapatkan nilai sebesar $50,48 \%$ sehingga perhitungan penghasilan bersih dari perhotelan dapat dikatakan memiliki kategori SEDANG. 
Pengisian Penghasilan Tidak Kena Pajak (PTKP)

Penilaian komitmen dalam Pengisian Penghasilan Tidak Kena Pajak (PTKP) dari perhotelan adalah sebesar 130 poin, dimana berdasarkan persentase poin tersebut didapatkan nilai sebesar $61,90 \%$ sehingga perhitungan penghasilan bersih dari perhotelan dapat dikatakan memiliki kategori TINGGI.

Pengenaan Tarif Pajak Penghasilan (PPh)

Penilaian komitmen dalam pengenaan tarif Pajak Penghasilan (PPh) dari perhotelan adalah sebesar 185 poin, dimana berdasarkan persentase poin tersebut didapatkan nilai sebesar $88,10 \%$ sehingga pengenaan tarif Pajak Penghasilan (PPh) dari perhotelan dapat dikatakan memiliki kategori SANGAT TINGGI.

Kelengkapan Data Pelaporan SPT Pajak

Penilaian komitmen dalam kelengkapan data pelaporan SPT Pajak dari perhotelan adalah sebesar 106 poin, dimana berdasarkan persentase poin tersebut didapatkan nilai sebesar 50,48\% sehingga kelengkapan data pelaporan SPT Pajak dari perhotelan dapat dikatakan memiliki kategori RENDAH.

Berdasarkan hasil analisis komitmen pelaporan SPT Pajak pada perhotelan, didapatkan analisis kategori yang menunjukkan bahwa sebagian besar jumlah perusahaan memiliki komitmen TINGGI sebanyak 21 perusahaan (50\%), namun masih terdapat 11 perusahaan (26,19\%) yang memiliki kategori RENDAH, dan 7 perusahaan (16,67\%) yang memiliki kategori SANGAT RENDAH. Tinggi komitmen pelaporan SPT Pajak pada perhotelan menunjukkan bahwa dalam perhitungan penghasilan bersih, pengisian penghasilan tidak kena pajak, pengenaan tarif PPh, dan pengisian kelengkapan data SPT telah dilakukan dengan baik dan benar.

Komitmen pelaporan SPT Pajak pada perhotelan menunjukkan bahwa terdapat 18 buah hotel, menggambarkan bahwa hotel-hotel tersebut belum tepat dalam menerapkan norma perhitungan atas penghasilan bersih yang didapat perusahaan setelah dikurangi biaya-biaya yang berkaitan dengan pengenaan pajak, salah dalam memperhitungkan penghasilan tidak kena pajak, tidak akurat dalam menetapkan tarif Pajak Penghasilan (PPh), 
Aranta Prista Dilasari: Analisis Komparatif Tentang Komitmen Wajib Pajak

serta belum benar dalam melengkapi data-data karakteristik obyek pajak.

\section{Restoran}

Penghitungan Penghasilan Bersih

Penilaian komitmen dalam perhitungan penghasilan bersih dari restoran adalah sebesar 81 poin, dimana berdasarkan persentase poin tersebut didapatkan nilai sebesar $62,31 \%$ sehingga perhitungan penghasilan bersih dari restoran dapat dikatakan memiliki kategori TINGGI.

Pengisian Penghasilan Tidak Kena Pajak (PTKP)

Penilaian komitmen Pengisian Penghasilan Tidak Kena Pajak (PTKP) dari restoran adalah sebesar 91 poin, dimana berdasarkan persentase poin tersebut didapatkan nilai sebesar $70 \%$ sehingga perhitungan penghasilan bersih dari restoran dapat dikatakan memiliki kategori TINGGI.

Pengenaan Tarif Penghasilan (PPh)

Penilaian komitmen dalam pengenaan tarif Pajak Penghasilan (PPh) dari restoran adalah sebesar 77 poin, dimana berdasarkan persentase poin tersebut didapatkan nilai sebesar 59,23\% sehingga pengenaan tarif Pajak Penghasilan (PPh) dari restoran dapat dikatakan memiliki kategori RENDAH.

Kelengkapan Data Pelaporan SPT Pajak

Penilaian komitmen kelengkapan data pelaporan SPT Pajak dari restoran adalah sebesar 87 poin, dimana berdasarkan persentase poin tersebut didapatkan nilai sebesar $66,92 \%$ sehingga kelengkapan data pelaporan SPT Pajak dari restoran dapat dikatakan memiliki kategori TINGGI.

Berdasarkan hasil analisis komitmen pelaporan SPT Pajak pada restoran, didapatkan analisis kategori yang menunjukkan bahwa sebagian besar jumlah perusahaan memiliki komitmen TINGGI sebanyak 20 perusahaan (76,92\%), namun masih terdapat 3 perusahaan (11,54\%) yang memiliki kategori RENDAH, dan 2 perusahaan (7,69\%) yang memiliki kategori SANGAT RENDAH. 
Ihtiyath Vol. 2 No. 1 September 2018

Tinggi komitmen pelaporan SPT Pajak pada restoran menunjukkan bahwa dalam perhitungan penghasilan bersih, pengisian penghasilan tidak kena pajak, pengenaan tarif PPh, dan pengisian kelengkapan data SPT telah dilakukan dengan baik dan benar.

Hal ini menunjukkan bahwa terdapat 6 buah restoran yang ternyata belum tepat dalam menerapkan norma perhitungan atas penghasilan bersih yang didapat perusahaan setelah dikurangi biaya-biaya yang berkaitan dengan pengenaan pajak, salah dalam memperhitungkan penghasilan tidak kena pajak, tidak akurat dalam menetapkan tarif Pajak Penghasilan (PPh), serta belum benar dalam melengkapi data-data karakteristik obyek pajak.

\section{PERBEDAAN KOMITMEN WAJIB PAJAK DALAM MELAPORKAN SPT PAJAK}

Perbedaan komitmen wajib pajak dalam melaporkan SPT Pajak pada perhotelan dan restoran dilakukan dengan menggunakan uji analisis statistik Independent Sample Test. Hal ini dikarenakan kedua kelompok data tersebut memiliki jumlah sampel yang berbeda, dimana sampel perhotelan berjumlah 42 perusahaan, sedangkan sampel pada restoran berjumlah 26 perusahaan.

Penghitungan Penghasilan Bersih

Hasil analisis perbedaan Penghitungan Penghasilan Bersih antara perhotelan dengan restoran dapat dilihat bahwa pada kolom Equal variances asummed menunjukkan nilai F adalah sebesar 0,854 dengan tingkat signifikan sebesar 0,359. Hal ini menunjukkan tidak adanya perbedaan varian dari kedua kelompok data perhitungan penghasilan bersih pada perhotelan dan restoran, sehingga dapat dinyatakan bahwa kedua kelompok data tersebut adalah bersifat homogen.

Selanjutnya apabila memperhatikan nilai t hitung sebesar 2,424 dengan nilai signifikan sebesar 0,018. Nilai t hitung tersebut lebih besar dari nilai t tabel $(2,424>1,997)$ maka dapat diambil gambaran yang jelas bahwa Penghitungan Penghasilan Bersih yang dilakukan oleh perhotelan dan restoran memiliki perbedaan yang signifikan. Hal ini juga diperkuat dengan nilai signifikan (2-tailed) dimana besarnya nilai signifikan tersebut lebih kecil dari 0,05. Adapun tanda minus (-) yang terdapat pada nilai t hitung menandakan bahwa mean rank varian yang dimiliki kelompok data pertama (perhotelan) lebih rendah dibandingkan 
Aranta Prista Dilasari: Analisis Komparatif Tentang Komitmen Wajib Pajak

varian pada kelompok data kedua (restoran), sehingga dapat dinyatakan bahwa restoran lebih tepat dalam melakukan perhitungan penghasilan bersih dibandingkan perhotelan.

\section{Pengisian Penghasilan Tidak Kena Pajak (PTKP)}

Hasil analisis perbedaan pengisian Penghasilan Tidak Kena Pajak (PTKP) antara perhotelan dengan restoran dapat dilihat bahwa pada kolom Equal variances asummed menunjukkan nilai $\mathrm{F}$ adalah sebesar 22,001 dengan tingkat signifikan sebesar 0,000. Hal ini menunjukkan terdapat adanya perbedaan varian dari kedua kelompok data pengisian Penghasilan Tidak Kena Pajak (PTKP) pada perhotelan dan restoran, sehingga dapat dinyatakan bahwa kedua kelompok data tersebut adalah bersifat tidak homogen.

Selanjutnya apabila memperhatikan nilai $t$ hitung sebesar 1,090 dengan nilai signifikan sebesar 0,280 . Nilai t hitung tersebut lebih rendah dari nilai t tabel $(1,090<1,997)$ maka dapat diambil gambaran yang jelas bahwa pengisian Penghasilan Tidak Kena Pajak (PTKP) yang dilakukan oleh perhotelan dan restoran tidak memiliki perbedaan yang signifikan. Hal ini juga diperkuat dengan nilai signifikan (2-tailed) dimana besarnya nilai signifikan tersebut lebih tinggi dari 0,05. Adapun tanda minus (-) yang terdapat pada nilai t hitung menandakan bahwa mean rank varian yang dimiliki kelompok data pertama (perhotelan) lebih rendah dibandingkan varian pada kelompok data kedua (restoran), sehingga dapat dinyatakan bahwa restoran lebih tepat dalam melakukan pengisian Penghasilan Tidak Kena Pajak (PTKP) dibandingkan perhotelan.

\section{Pengenaan Tarif Penghasilan (PPh)}

Hasil analisis perbedaan pengenaan tarif Penghasilan (PPh) antara perhotelan dengan restoran dapat dilihat bahwa pada kolom Equal variances asummed menunjukkan nilai $\mathrm{F}$ adalah sebesar 5,858 dengan tingkat signifikan sebesar 0,018. Hal ini menunjukkan terdapat adanya perbedaan varian dari kedua kelompok data pengenaan tarif Penghasilan (PPh) pada perhotelan dan restoran, sehingga dapat dinyatakan bahwa kedua kelompok data tersebut adalah bersifat tidak homogen.

Selanjutnya apabila memperhatikan nilai t hitung sebesar 7,331 dengan nilai signifikan sebesar 0,000. Nilai t hitung tersebut lebih tinggi dari nilai t tabel $(7,331>1,997)$ maka dapat diambil gambaran yang jelas bahwa pengenaan tarif Penghasilan (PPh) yang dilakukan 
Ihtiyath Vol. 2 No. 1 September 2018

oleh perhotelan dan restoran memiliki perbedaan yang signifikan. Hal ini juga diperkuat dengan nilai signifikan (2-tailed) dimana besarnya nilai signifikan tersebut lebih rendah dari 0,05. Tidak adanya tanda minus (-) pada nilai t hitung menandakan bahwa mean rank varian yang dimiliki kelompok data pertama (perhotelan) lebih tinggi dibandingkan varian pada kelompok data kedua (restoran), sehingga dapat dinyatakan bahwa perhotelan lebih tepat dalam melakukan pengisian terhadap pengenaan tarif Penghasilan (PPh) dibandingkan restoran.

\section{Kelengkapan Data Pelaporan SPT Pajak}

Hasil analisis perbedaan kelengkapan data pelaporan SPT Pajak antara perhotelan dengan restoran dapat dilihat bahwa pada kolom Equal variances asummed menunjukkan nilai $F$ adalah sebesar 0,355 dengan tingkat signifikan sebesar 0,554. Hal ini menunjukkan tidak adanya perbedaan varian dari kedua kelompok data kelengkapan data pelaporan SPT Pajak pada perhotelan dan restoran, sehingga dapat dinyatakan bahwa kedua kelompok data tersebut adalah bersifat homogen.

Selanjutnya apabila memperhatikan nilai t hitung sebesar 2,950 dengan nilai signifikan sebesar 0,004. Nilai t hitung tersebut lebih besar dari nilai t tabel $(2,950>1,997)$ maka dapat diambil gambaran yang jelas bahwa kelengkapan data pelaporan SPT Pajak yang dilakukan oleh perhotelan dan restoran memiliki perbedaan yang signifikan. Hal ini juga diperkuat dengan nilai signifikan (2-tailed) dimana besarnya nilai signifikan tersebut lebih kecil dari 0,05. Adapun tanda minus (-) yang terdapat pada nilai t hitung menandakan bahwa mean rank varian yang dimiliki kelompok data pertama (perhotelan) lebih rendah dibandingkan varian pada kelompok data kedua (restoran), sehingga dapat dinyatakan bahwa restoran memiliki kelengkapan data pelaporan SPT Pajak dibandingkan perhotelan.

\section{Komitmen Pelaporan SPT Pajak}

Hasil analisis perbedaan komitmen pelaporan SPT Pajak antara perhotelan dengan restoran dapat dilihat bahwa pada kolom Equal variances asummed menunjukkan nilai $\mathrm{F}$ adalah sebesar 7,083 dengan tingkat signifikan sebesar 0,010. Hal ini menunjukkan adanya perbedaan varian dari kedua kelompok data komitmen pelaporan SPT Pajak pada perhotelan dan restoran, sehingga dapat dinyatakan bahwa kedua kelompok data tersebut adalah tidak bersifat homogen. 
Aranta Prista Dilasari: Analisis Komparatif Tentang Komitmen Wajib Pajak

Selanjutnya apabila memperhatikan nilai t hitung sebesar 1,488 dengan nilai signifikan sebesar 0,141. Nilai t hitung tersebut lebih rendah dari nilai t tabel sebesar 1,997 (Lampiran Tabel Distribusi t; halaman 91) maka dapat diambil gambaran yang jelas bahwa komitmen pelaporan SPT Pajak yang dilakukan oleh perhotelan dan restoran tidak memiliki perbedaan yang signifikan. Hal ini juga diperkuat dengan nilai signifikan (2-tailed) dimana besarnya nilai signifikan tersebut lebih tinggi dari 0,05. Adapun tanda minus (-) yang terdapat pada nilai thitung menandakan bahwa mean rank varian yang dimiliki kelompok data pertama (perhotelan) lebih rendah dibandingkan varian pada kelompok data kedua (restoran), sehingga dapat dinyatakan bahwa restoran memiliki komitmen pelaporan SPT Pajak yang lebih tinggi dibandingkan perhotelan.

Berdasarkan hasil uji beda dari komitmen Pelaporan SPT Pajak antara perhotelan dengan restoran, maka hipotesis dasar yang menyatakan bahwa "tidak terdapat perbedaan yang signifikan mengenai komitmen wajib pajak dalam melaporkan SPT pajak antara perhotelan dan restoran" adalah DITERIMA. Sedangkan hipotesis alternatif yang menyatakan bahwa "terdapat perbedaan yang signifikan mengenai komitmen wajib pajak dalam melaporkan SPT pajak antara perhotelan dan restoran” adalah DITOLAK.

Hal ini menandakan bahwa perlu adanya penanganan yang sama berupa perhatian dan pengawasan yang lebih terhadap wajib pajak berdasarkan kriteria usahanya, sehingga terdapat adanya penyesuaian agar komitmen pelaporan SPT pajak dapat ditingkatkan.

\section{Saran Penelitian}

Berdasarkan kesimpulan penelitian yang telah dikemukakan, maka saran-saran penelitian adalah sebagai berikut:

Pemerintah melalui Dinas Pendapatan Daerah dan Kantor Pelayanan Pajak (KPP Prata$\mathrm{ma}$ ) Semarang diharapkan dapat melaksanakan usaha-usaha dalam meningkatkan komitmen wajib pajak mengenai Pelaporan SPT Pajak, yang antara lain adalah :

Memberikan arahan agar obyek pajak dapat menerapkan perhitungan atas penghasilan bersih yang didapat perusahaan setelah dikurangi biaya-biaya yang berkaitan dengan pengenaan pajak. 
Ihtiyath Vol. 2 No. 1 September 2018

Menekankan kepada obyek pajak mengenai pentingnya pemberian informasi mengenai pendapatan-pendapatan yang tidak terkena tarif pajak, seperti pendapatan lain-lain, pendapatan bunga dan pendapatan non operasional lainnya, yang dilaporkan dalam SPT Pajak.

Memberikan pengarahan kepada obyek pajak mengenai pentingnya keakuratan dalam perhitungan dasar pengenaan tarif Pajak Penghasilan (PPh) atas obyek pajak.

Para pengusaha, khusus perusahaan yang bergerak dalam bidang perhotelan dan restoran diharapkan dapat memperhatikan dan memelihara norma pelaporan SPT pajak, mengenai kebenaran atas kelengkapan data-data mengenai informasi obyek pajak serta komponen-komponen yang berkenaan dengan karakteristik obyek pajak.

\section{DAFTAR PUSTAKA}

Arikunto, Suharsimi, 2021. Prosedur Penelitian Suatu Pendekatan Praktek Edisi Revisi. Jakarta: PT. Rineka Cipta.

Halim, Abdul. 2014. Pajak di Indonesia. Bandung: Alfabeta.

Mardiasmo. 2015. Perpajakan edisi revisi. Yogyakarta: Andi Offset.

Muchlas, Makmuri. 2008. Perilaku Organisasi. Yogyakarta: Gadjah Mada University Press. Muqodim. 2011. Perpajakan. Buku Satu, Edisi 2. Yogyakarta: UII Press.

Notoatmodjo, Soekidjo. 2014. Metodologi Penelitian Kesehatan. Jakarta: PT Rineka Cipta.

Rahardjo, Mudjia. 2010. Artikel dan Jurnal Metode Penelitian. http://mudjiarahardjo. com/artikel/165-pak-bisakah-kedua-metode-penelitain-itu-digabung.html (Diunduh tanggal 3 Januari 2013).

Resmi, Siti. 2013. Perpajakan; Teori dan Kasus, Penerbit Salemba Empat, Jakarta.

Suandy, Early. 2012. Hukum Pajak. Jakarta: Salemba Empat.

Sugiono. 2012. Metode Penelitian Bisnis. Bandung : Penerbit Alfabeta.

Suhartono. 2010. Panduan Komprehensif, Mudah dan Praktis Pajak Penghasilan. Edisi Revisi. Jakarta: Fakultas Ekonomi Universitas Indonesia. 
Sumitro, Rahmat. 2004. Perpajakan. Jakarta: Salemba Empat.

Wahyudi. 2012. Manajemen Pelayanan Publik. Jakarta: Radja Grafindo Persada.

Waluyo dan Wirawan B. Ilyas, 2002, Perpajakan Indonesia, Edisi Revisi, Penerbit Salemba Empat. Jakarta.

Waluyo. 2008. Perpajakan Indonesia. Jakarta : Penerbit Salemba Empat.

UU RI No. 6 tahun 1983 tentang Surat Pemberitahuan (SPT) 